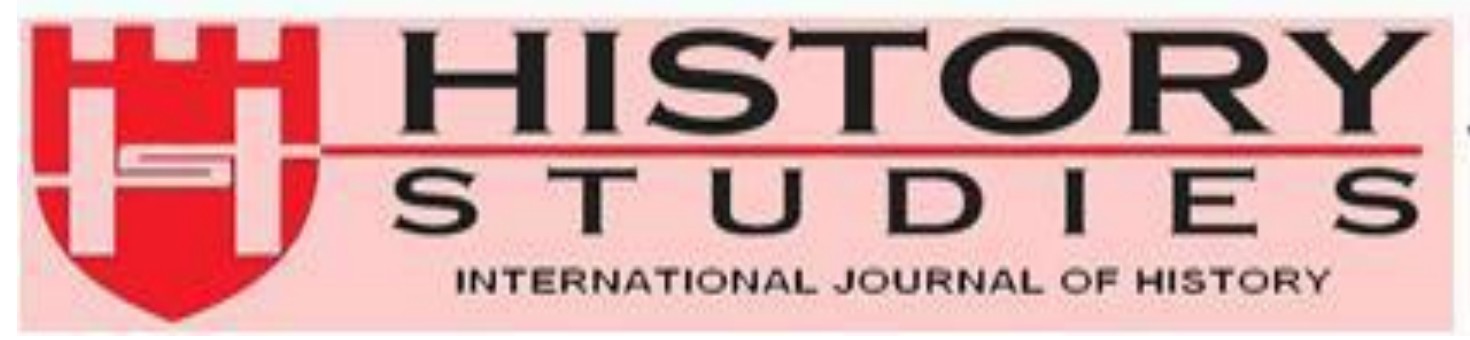

ISSN: 13094173 (Online) 1309 - 4688 (Print)

Volume 8 Issue 2, p. 125-137, June 2016, DOI Number: 10.9738/hişt.2016220345

\title{
Milli Destanlara Göre Sekellerin Menşei
}

Genesis of Szekelys According to National Legends

\author{
Pınar YİĞİT TÜRKER \\ Doktora Öğrencisi- Ankara Üniversitesi - Ankara
}

\begin{abstract}
Öz: Bu çalışma Sekellerin etnik kökenine dair çalışmaları ve Sekel milli destanlarında geçen menşe hikâyelerini inceleyerek, Sekellerin menşeine dair tartışmalara ışık tutmayı amaçlamaktadır. Sekellerin kimliğine dair tartışmalar onların Türkî unsurların doğubatı yönünde Avrupa içlerine kadar yürütmüss oldukları göç serüveninin bir öğesi oldukları konusunda sağlam bulgulara dikkat çekmekte, aradan geçen uzun asırlar ve Hıristiyanlı̆̆ın etkisine rağmen Sekel kültürünün kendine has özelliklerinin muhafaza edildiği sonисипи ortaya koymaktadir.
\end{abstract}

Anahtar Kelimeler: Sekeller, Hunlar, Macarlar, Türkler, Destanlar

Abstract: This study anayzes the works on the genesis of Szekelys and examines Szekely legends to trace their orgins. Previous works and Szekely legends indicate that Szekelys are related to Turkic elements, who migrated to Europe and embraced Christianity but preserved their customs and traditions.

History Studies Volume 8 Issue 2 June 2016

Keywords: Szekelys, Huns, Hungarians, Turks, Legends

\section{Giriş}

Macar tarihinin çözülmeyi bekleyen sorunlarından biri de Sekellerin menşei meselesidir. Menşe konusu ile ilgili yüzyıllar öncesinden intikal etmiş kaynaklar kesin bir malumat vermekten uzaktırlar. Bu konunun açıklığa kavuşturulması ileride Sekel milli tarihinin de seyrini belirlemesi açısından mühimdir. Sekeller askeri vazifeler yürüten ayrıcalıklı bir toplum olarak XV. asrın ikinci yarısına kadar Macar toplumu içindeki haklarını başarıyla muhafaza ettiler. Ancak arkaik açıdan onlardan ayrı bir halk olduklarını da hissetmekteydiler. Eski kronikler Hun-Macar-Sekel ortak etnisitesine dikkat çekmektedirler. Ancak XIX. ve XX. asrın siyasi ve kültürel atmosferi Macar ve Sekel etnik yapısının yeniden ele alınmasına ve ortaya yeni ve bir o kadar da ilginç iddiaların atılmasına sebep olmuştur. Şimdi bu iddialara kısaca bir göz atalım.

\section{Sekellerin Menşeine Dair Görüşler}

Sekellerin etnik kökenine dair tartışmalar oldukça farklı iddiaların gündeme gelmesine sebebiyet vermiştir. Bu tartışmalar Sekellerin Hun oldukları ${ }^{1}$ ya da kesinlikle olmadıkları, ${ }^{2}$

\footnotetext{
${ }^{1}$ Anonymus, Gesta Hungarorum, Forditotta: Pais Dezső, Magyar Helikon 1977, s. 26; Simon Kézai, Magyar Krónıkája, Szerkeszti: Radó Antal, Budapest 1901, s. 30-31; Thuróczi János, A Magyarok Krónikája, Helikon Kiadó, Budapest 1986; Antonio Bonfini, A Magyar Történelem Tizedei, Fordította: Péter Kulcsár, Balassi Kiadó, Budapest 1995, s. 82 .
} 
Hun-Hazar-Bulgar kökenli oldukları, ${ }^{3}$ Sabir-Hun kabilelerinin Eszegel boyuna mensup oldukları, ${ }^{4}$ Peçenek oldukları, ${ }^{5}$ Got oldukları, ${ }^{6}$ Hun-Avar kökenli oldukları, ${ }^{7}$ Doğu Sekellerin Hazar, Batı Sekellerin Avar kökenli oldukları, ${ }^{8}$ Macar kökenli olduklar $1,{ }^{9} 894$ Bulgar tutsağın soyundan geldikleri, ${ }^{10}$ Gepid kökenli olduklar ${ }^{11}$ ve Türk kökenli oldukları ${ }^{12}$ gibi birbirinden oldukça farklı mecralarda seyretmiştir. Bu iddiaların ortaya atılış gerekçesi ve dayandıkları ilmi metotlar konumuzu aşacağından burada sadece belli başlı iddialara yer vermekle yetineceğiz. ${ }^{13}$

Macar kaynaklarında ilk kez 1116 yılı olayları anlatılırken Sekellerden bahsedilmektedir. XIV. yüzy1la ait Képes Krónika'da (The Chronicon Pictum) Macar Kralı II. İstvan'ın (11161131) Çekler ile girdiği mücadelede Sekel ve Peçenek okçularının gerektiği gibi yararlılık gösteremediklerinden bahsedilmektedir. ${ }^{14}$ Aynı kronikte buna benzer bir diğer hikâye de Macar Kralı II. Geza (1141-1162) ile Avusturya Dükü II. Henry (1140-1156) arasında 1146

\footnotetext{
${ }^{2}$ Timon Sámuel, Epitome Chronologica Rerum Hungaricarum, Cassovia 1734, Benkő József, Transsilvania Specialis Erdély Földje és Népe, C. I., Fordította: Szabó György, Kriterion Könyvkiadó, Bukarest-Koloszvar 1999; ayrıca aynı doğrultuda görüş bildiren Pray György, Fejér György, Kállay Ferenc ve Horvát István için bkz. S. Kardoss Lajos, A Szekely Nemzet Tortenete es Alkotmanya, Budapest 1927, s. 8; Sekellerin Hun kökenli değil I. László'nun eski sınır muhafızları oldukları yönünde görüş bildiren Hunfalvy Pál için bkz. Hunfalvy Pál, Magyarország Ethnographiája, A Magyar Tudományos Akadémia Könyvkiadó-Vállalata, Budapest 1876.

${ }^{3}$ Pauler Gyula, A Vezerek Kora István Kırálylg, Magyar İskutatis Kiadása, Buenos Aires 1974, s. 51; SzádeczkyKardoss Lajos, A Szekely Nemzet Tortenete es Alkotmanya, Budapest 1927; Sekel etnisitesinde Hazar katılımı vardır diyen Györffy György için bkz. Györffy György, A Székelyek Eredete és Településük Története, in Erdély és népei, szerk. Mályusz Elemér, Budapest 1941, s. 35-86 ; Hun-Avar-Bulgar iştirakine dikkat çeken László Gyula için bkz. László Gyula, Árpád Népe, Monográfia, Magyar Helikon, Budapest 1988; Bulgar katılımı var diyen Kristó Gyula için bkz. Kristó Gyula, Levedi Törzsszövetségétöl Szent István Államáig, Budapest 1980, s. 172-191; Hazar/Bulgar-Türk etkisine vurgu yapan Szűcs Jenő için bkz. Szűcs Jenő, “A Középkori Magyarország Népei”, I. História, 1982/4-5, s. 3.

${ }^{4}$ Nagy Géza, Az Eszegel Bolgárok Neve, Századok 1914.

5 Tagányi Károly, “A Honfoglalás és Erdély”, Ethnographia, 1890, s. 213; Réthy László, “A székelyek es a Magyar Honfoglalás”, Ethnographia, 1890, s. 25.

${ }^{6}$ Borovszky Samu, “Hun-Magyar Rokonságról”, Ethnographia, 1894, s. 100.

7 Thúry József, A Székelyek Eredete, Erdélyi Múzeum, 1898; Hóman Bálint, A Székelyek Eredete, A Magyar Nyelvtudományi Társaság Kiadványai 17, Budapest.1921; Miklós Asztalos, A székelyek östörténete letelepedésükig, Cluj-Kolozsvár 1932; Pais Dezső, A magyarsággal Kapcsolatos IX-X. Századi Népelemek és Népmozgalmak. A Székelyek Eredetéhez és a Székelység Kialakulásához, Magyar Nyelv, 1967, s. 71-73.

${ }^{8}$ Sebestyén Gyula, Az Avar-Székely Kapcsolat Pere, Válasz Thúry Józsefnek, Erdélyi Múzeum 1899; ayrıva bkz. Sebestyén Gyula, “Az Avar-Székely Kapcsolat Emlékei” Ethnographia, 1899, s. 1-25.

${ }^{9}$ Karácsonyi János, A Székelyek Eredete És Erdélybe Való Települése, Budapest 1905; ekseriyeti Macar diyen Mályusz Elemér için bkz. Mályusz Elemér, A Székelység Eredetéröl, Emlékkönyv Melich János Hetvenedik Születésnapjára, Budapest 1942; ayrıca Sekel-Macar ortak etnisitesine vurgu yapan görüşler için bkz. Benkö Loránd, "Nyelvész Szemmel a Székelyekről”, Beszélgetés Benkő Loránd Akadémikussal, Új Tükör, C. 7, Szeged 1980, s. 22-23; Mesterházy Károly, Nemzetségi Szervezet és az Osztályviszonyok Kialakulása a Honfoglaló Magyarságnál,Budapest 1980; Balázs János, Levédia, Nyék... és a Székelyek Eredete, Magyar Deákság, Anyanyelvünk és az Európai Nyelvi Modell, Budapest 1980.

${ }^{10}$ Erdélyi László, A Székelyek Eredete, Szent Bonaventura Könyvnyomda, Kolozsvár 1918.

${ }^{11}$ Karácsonyi János, A Székelyek Ösei és a Székely Magyarok, Cluj-Kolozsvár 1924.

${ }^{12}$ Sekellerin Türk/Hazar kökenli olduğunu belirten Németh Gyula için bkz. Németh Gyula, $A$ Székelyek Eredetének Kérdése, Szeged 1935; Türk/Çiğil-Hazar bağlantısına vurguypan Moór Elemér_için bkz. Moór Elemér, $A$ Honfoglaló Magyarság Megtelepülése és a Székelyek Eredete, Szeged 1944.

${ }^{13}$ Sekellerin menşeine dair iddialar için bkz. Zoltan Kordé, Székelykérdés Története, Székelyudvarhely 1991, s. 514.

14 “And olsun ki inandı̆̆ın ve duyduğun her şey doğru: Onlar Çeklerin üzerlerine doğru geldiğini gördüler. Aşă̆gllk Peçenek ve Sekeller hiç yara almadan Kralın karargâhına geri döndüler”. Bkz. Képes Krónika, Fordította: Geréb László, Magyar Hírlap és Maecenas Kiadó, Budapest 1993, s. 53. 
yılında vuku bulan Fischa Savaşı vesilesiyle dile getirilmektedir. ${ }^{15}$ En eski Macar kroniklerinin belirttiği üzere Macarların Sekellere harplerde ön saflarda görev vermesi Türk askeri teşkilatının bir uygulaması olarak dikkat çekmektedir. Zira Macarlar da tıpkı Türkler gibi yeni iltihak eden boyları savaşlarda öncü kuvvet olarak bulundurmaktaydılar. László Rasonyi bu hususa dikkati çekerek Sekellerin Macarlara XII. yüzyılda katıldığı fikrini dile getirmiştir ki zaten Macar kaynaklarından edindiğimiz malumat da bu görüşle örtüşmektedir. ${ }^{16}$

Sekeller hakkındaki bir sonraki malumat1 XIII. yüzyıl itibariyle Anonymus'un Gesta Hungarorum adlı eserinde III. Béla (1172-1196) dönemi olaylarını aktarması vesilesi ile edinmekteyiz. Anonymus'un anlattıklarından Sekeller, Macarların Pannonia'ya ${ }^{17}$ girip bu bölgenin hâkimi Mén-Marót ile savaşa tutuştukları esnada onlara katılmışlardır. İki taraf arasında Tisa Nehri (Tiszá) yakınlarındaki Kórógy'de gerçekleşen toplantı eserde şöyle nakledilmektedir:

Ösbönek ile Mén-Marót arasındaki ilk savaş başlamadan önce Ösbönek Sekellerden bir haber aldı. Onlar Hun Kralı Attila'nın eski halkıydılar ve barıs yanlısı olduklarını söylediler. Gönül rızası ile çocuklarını rehin olarak gönderdiler ve çeşitti hediyeler sundular. ${ }^{18}$

Macar Kralı IV. László’nun (1272-1290) katipliğini yapan Simon Kézai 1282 y1lı dolaylarında Latince kaleme aldığı Gesta Hunnorum et Hungarorum adlı eserinde ileride Sekellerin kendilerini Hunlar ile özleşleştirmelerine neden olacak o meşhur malumatı vermektedir. Anlatılana göre Attila'nın ölümünden sonra iki oğu Aladár ve Çaba (Csaba) arasında Krimhilda Savaşı adı verilen kanlı bir mücadele yaşandı ve sonuçta Çaba'yı destekleyen sayıları 15.000 olan Hunlar mağlup edildi. Çaba geriye kalan 3.000 Hun atlısı ile birlikte Yunanistan'a doğru çekildi. Bu Hunlar Csigle denen yerde durdular ve Árpád (895907) çağına kadar burada kaldılar. Kendilerini Prens Çaba'ya hasreden bu Hun bakiyesi, Macarlar Pannonia'yı fethettiği sırada tekrar gelerek onlara katıldılar ve Ruthenia'nın (Karpatlar) fethinde iştirak ettiler. ${ }^{19}$

Hunfalvy Pál, Gesta Hungarorum ve Simon Kézai Kronikası gibi eski Macar kroniklerinde geçen Sekellerin Hunların ahfadı olduğuna dair bilgilerin birer hikâyeden ibaret olduğunu ve bunun tarihi gerçeklerle uyuşmadığını düşünmektedir. Zira bu bilginin diğer Macar vesikaları tarafından doğrulanamıyor olması Hunfalvy Pál'i bu konuda temkinli olmaya sevk etmiştir. Pál, 1876 yılında neşrettiği Magyarország Ethnographiája adlı eserinde Sekellerin Hunların neslinden gelmediklerini nispeten Slav ve Türk etkisine maruz kalmış olan ve Macar Kralı I. László'nun (1077-1095) eski sınır muhafızlı̆̆ı (határőrzök) görevini üstlenen bir topluluk olduğu görüşündedir. ${ }^{20}$

\footnotetext{
15 “Macar askerleri önünde yer alan kötü ve aşağıllk Peçenek ve Sekeller her zamanki gibi kurt görmüş koyun misali aynı anda kaçıp gittiler”. Bkz. age, s. 58.

${ }^{16}$ László Rasonyi, “Ortaçağ’da, Erdel'de Türklüğün İzleri”, Belleten, C. II, S. 5/6, TTK Basımevi, Ankara 1938, s. 109.

${ }^{17}$ Eskiden bir ileri Roma eyaleti olan Pannonia, Kavimler Göçü esnasında tamamen harap hale gelmişti ve 889 y1lı itibariyle Bulgar ve Peçenek baskısıyla Etelköz'den (bugünkü Moldova ile Basarabya) ayrılan Macarlar Árpád'ın önderliğinde gelerek bu bölgede yurt tutmaya başladılar. Macarlar, Hunların hatıralarının henüz silinmediği bu bölgede tıpkı onlar gibi Tisa Nehri civarındaki verimli otlaklara yerleştiler. Bkz. F. Eckhart, Macaristan Tarihi, Çev. İbrahim Kafesoğlu, TTK Basımevi, Ankara 2010, s. 8-10.

${ }^{18}$ Anonymus, age, s. 26.

${ }^{19}$ Kézai, age, s. 30-31.

20 Hunfalvy Pál, Magyarország Ethnographı́aja, A Magyar Tudományos Akadémia Könyvkiadó-Vállalata, Budapest 1976, s. 299-301.
} 
Ferenc Eckart, Macar Krallığı'nın sınır hattı boyunca (gyepü) akraba kavimlerden gelebilecek saldırılara karşı müdafaa görevi üstlenen Sekellerin Kabarların (Hazar) Macarlaşmış nesilleri olduğu görüşündedir. Sekeller tüm gyepü kuşağı boyunca: Yukarı Tisa'da, Vag vadisinin çok defa Çek taarruzuna maruz noktalarında, Drava'da, Szerem ilinde, Aşağı Tuna'da muhafiz olarak bulunuyorlar, fakat en büyük kitleleri Kuman hücumlarına karşı doğu kapılarını muhafaza ediyorlardı. ${ }^{21}$

Homan Balint'e göre, Türkçe bir kelime olan Szekely "hükümdar oğlu kavmi" manasına gelmektedir. Erdel bölgesinin de içinde bulunduğu coğrafya Roma'nın Tuna havzasını boşaltması ardından Germen kavimleri tarafından istila edilmiş bir süre sonra ise Hunlar tarafından domine edilmek suretiyle birleştirilmiştir. Attila'nın ölümü ardından Avar etkisine giren Tuna ve Tisa nehirlerinin suladığ 1 Karpatya bölgesi, Macarların X. asırda gerçekleştirdiği fetihler esnasında yeni bir siyasi oluşuma sahne olmuştur. Sekellerin ve Peçeneklerin de iştirakiyle tesis edilen Macar Krallığı eski Hun-Avar mirası üzerinde yükselen ve onun kalıntılarıyla beslenen bir oluşumdu. Sekellerin harpte ön saflarda ve sınır boylarındaki kalelerde görev yaptığı XII. asır kroniklerinde açık bir şekilde görülmektedir. Balint'e göre Sekeller, Macarların yurt işgalinden evvel Avarlarla sürüklenip gelen Bulgar, Onogur ve yahut Attila'nın Hun devletine tabi, Bulgar ve Macar unsurlarla karışmış bir Avar zümresi olmalidir. ${ }^{22}$

Sekel etnik yapısına dair bir diğer görüş de onların Proto-Bulgar Türk kabileleri ile akraba oldukları yönündedir. Bu konuda incelemeler yapan István Vásáry’e göre Sekellerin asıl şekli "Sekel, Sekül” olan isimleri, Bulgar-Türk "Eksel" kabilesi ile alakalı olabilir. Bu isme Volga Bulgarlarında da rastlamak mümkündür. Vásáry, Sekellerin Ortaçağ’ da yaygın olarak inanılan Hun menşeli oldukları inancının da ancak Bulgar-Türk ilişkileri ile açıklanabileceği görüşündedir. Zira Bulgar halkları, 453'te Attila'nın ölümünü müteakip Karadeniz bölgesine çekilen Hunlar ile 463 dolaylarında aynı bölgeye gelen Ogur halklarının karışımından ortaya çıkmıştır. ${ }^{23}$

László Rasonyi, Erdel bölgesinde bulunan yer adlarının etimolojik kökenine değinerek bu coğrafyadaki yoğun Türk etkisine dikkat çekmektedir. Rasonyi’ye göre Erdel bölgesindeki Türkî unsurlar, X. asırda Macarların bölgeyi zaptından çok önce burada bulunmaktaydı. Macarların bölgeye gelişiyle birlikte Hunların ve Avarların eski bağdaşıkları olan bu topluluklar onlara tabi olmuşlardı. Zira eski Macar kroniklerindeki bilgiler Sekellerin de bu topluluklar arasında bulunduğunu ve onların yaşadığı bölgenin Csigle (Çığla) olduğunu gösteriyor. Rasonyi, Csigle'nın da Erdel'deki diğer birçok yer ismi gibi Türkçe bir isim olduğunu ve Çig: yüksek set ve yer ismi türetmeye yarayan -le (yayla, kışla) ekinden türediğini dile getirmektedir. Rasonyi’nin bu tespitleri Erdel'deki Sekel etnisitesinin Türkî unsurlarla ilişkilendirilmesi yönünde ciddi veriler sunmaktadır. ${ }^{24}$

XIX asır itibariyle Sekellerin Asiatik ve Türkî özellikler taşıdıklarına ait kanı artık yavaş yavaş ortaya çıkmakla birlikte onların Avrupa içlerine kadar nasıl ilerledikleri ve eski Türk yurdu ile olan bağlantıları gizemini korumaktaydı. Bu konuda Orhun Yazıtlarının keşfi ve deşifre edilmesi dönüm noktası oldu. Yazıtlarda İzgil²5 adında bir milletten bahsedilmesi Sekel

${ }^{21}$ E. Eckhart, age, s. 42.

${ }^{22}$ Homan Balint,"Szekelyliler”, Çev. Hamit Z. Koşay, Belleten, C. V, S. 20, TTK Basımevi, Ankara 1941, s. 601.

${ }^{23}$ István Vásáry, “Doğu Avrupa’nın Runik Yazı Sistemleri Üzerine”, TDAY-B, Ankara 1993, s. 54-55.

${ }^{24}$ László Rasonyi, “Ortaçağ'da, Erdel'de Türklüğün İzleri”, Belleten, C. II, S. 5/6, TTK Basımevi, Ankara 1938, s. $108-110$.

25 Kül Tigin Yazıtı, Kuzey 3-4 “Amcam (Kapgan) kağanın ili sarsıldı̆̆ında; millet, hükümdar ikiye ayrıldı̆̆ında; İzgil milleti ile savaştık. Köl Tigin Alp Saçlı atına binip atılarak hücum etti. O at orada düştü. İzgil milleti öldü”. 
etnisite tartışmalarına yeni bir açılım getirdi. Sekellerin Orta Asya Türk boylarıyla olan bağlantısı üzerine araştırmalar yapan J. Thury, Sekel isminin eski Macarcadaki "sikül” ve "sekül" şekillerini, Çağatayca'da rastlanan "sikil", yani "necip, soylu, nesli pak olan beyzade" sözüyle mukayese ederek bu milletin Türk kökenli bir soya dayandığı görüşünü dile getirmiştir. Türkçede rütbe isimlerine genellikle kabile ismi olarak da rastlanıyor olması Thury'nin bu görüşünü destekler niteliktedir. ${ }^{26}$

Sekellerin izlerini eski Türk yurdunda arayan Bahaeddin Ögel, Kadırgan'dan Güney Rusya'ya kadar yayılmış bulunan ve etnik açıdan ortak özellikler taşıyan Töles boylarından biri üzerinde 1srarla durmaktadır. Szu-chien (Sikil) boyu ve bu boyun etnik açıdan benzerlik taşıdığ $1 \mathrm{Nu}$-shih-pi'lere bağlı Asgil boyunun doğu batı yönünde gerçekleştirdiği hareketlilik dikkat çekicidir. Kök Türkçe kitabelerde de İzgil olarak zikredilen, ancak Kök Türkler ile farklı bir dil konuştukları söylenen bu Töles boyu VIII. asır ile birlikte ağır kayıplar vererek batıya doğru göç etmek zorunda bırakılmıştır. Ögel bu boyun bir süre Volga Bulgarları ile birlikte yaşadığı ve Esgil olarak anıldığını söylemekte Macar ve Bulgar tesirine maruz kaldıklarını belirtmektedir. Ögel bu suretle Erdel'de bulunan Sekellerin Batı Kök Türk federasyonuna bağlı bir Töles boyu iken batıya gelerek Bulgar ve Macar etkisinde kaldıklarını ancak eski hatıralarını bilhassa da Kök Türk runik yazı sistemini bu topraklara getirdiklerini söylemektedir. ${ }^{27}$

Kök Türkçe metinlerde Sekel izlerini takip eden Saadettin Gömeç'e göre kitabelerde Çik Il (Sek El) olarak zikredilen ve Sayan-Hakas coğrafyasında ikamet eden boy, Hun birliğinin dağılma sürecince parçalanarak bir kısmı İrtiş Nehri'ni geçip MS II. asır dolaylarında İdil-Ural sahasına yerleşmiştir. Bu bölgede Avrupa Hun Federasyonu'na dâhil olan Çik Illliler, Avrupa Hunlarının parçalanması ardından Avarlar ve Bulgarlar ile iletişim halinde yaşamaya devam ederek X. asrın başlarından itibaren Orta Avrupa'ya gelerek yurt tutan Macarlara iştirak etmişlerdir. $^{28}$

İlk tarihi kroniklere Hun Kralı Attilla'nın oğlu Prens Çaba'nın ahfadı olarak kaydedilen Sekellerin tam olarak hangi menşeden geldikleri hakkında sonraki asırlarda net bir kaydın bulunmuyor olması yukarıda zikrettiğimiz bilim adamlarının birbiriyle çelişen iddialar ortaya atmalarına neden olmuştur. Anlaşılan o ki Macarların Pannonia'yı işgali sırasında karşılaştıkları Sekellerin, tıpkı kendileri gibi Hunlara aidiyet hissetmesini kendileri açısından bir kazanıma dönüştürmek isteyen Macar ileri gelenleri, bir yakınlık algısı yaratma gayreti içine girmişlerdir. Ancak Sekellerin diğer tabi kabilelerle aynı statüde tutulması, özellikle de askeri teşkilattaki yerleri Macarların bu yakınlığ tam olarak benimsemedikleri izlenimi yaratmaktadır. Hatta bazı kroniklerde Sekellerin gerektiği gibi savaşmadığını belirten Macarlar onlardan esefle bahsetmektedirler. Yapılan modern çalışmalar Sekel menşeini Asya bozkırlarına kadar uzanan geniş bir sahada aramamız gerektiğini göstermektedir. Bu açıdan Sekel etnisitesini Türk, Hun, Hazar, Bulgar, Avar, Peçenek vs. gibi Asya topluluklarıyla açılayan görüşler birbiriyle yakınlık arz etmektedir. Buna mukabil zaman zaman Sekellleri Germanik topluluklarla ilişkilendirmek isteyen görüşler ortaya atılsa da bu fikirlerin çok kabul görmediği anlaşılmaktadır.

${ }^{26}$ László Rasonyi, Doğu Avrupa'da Türklük, Selenge Yayınları, İstanbul 2006, s. 71.

${ }^{27}$ Bahaeddin Ögel, "Sekellerin Ataları Hakkında (Sikil, Esgil Boyları)", Belleten, C. IX, S. 36, TTK Basımevi, Ankara 1945, s. 483.

${ }_{28}$ Saadettin Gömeç, "Türk Tarihinde Sek El-Çik-Çigil Meselesi”, Ankara Üniversitesi Dil ve Tarih-Coğrafya Fakültesi Türkoloji Dergisi, C. 18, S. 2 (2011), s. 56-57. 
Görüldüğü üzere Sekel etnik yapısı, yaşadıkları bölgenin siyasi ve kültürel ortamı gereği zaman içerisinde oldukça farklı iddialara konu edilmiştir. Ancak ilmi bakımdan Sekellerin menşei hala bir kesinlik arz etmemektedir. Sekel toplumunun algısı ise yapılan bu tartışmaların tamamen dışında kalmış kendi tarihsel ve kültürel serüvenleri içinde bugünlere intikal etmiştir. Şöyle ki, bir Sekel nazarında Hun olmanın hele bir de Attila'nın soyundan geliyor olmanın verdiği gurur, haklarında yazılan ve söylenen onca şeyin önüne geçmiş durumdadır. Eski Macar kroniklerinin verdiği malumat Macar ve Sekel efsaneleri ile harmanlanarak bir tarih algısı meydana getirmiş ve içinde yoğun Türk izlerinin de bulunduğu bu varoluş reçetesi Sekellerin hapsoldukları dar coğrafyada erimelerine mani olan bir milli şuura dönüşmüştür. Şimdi Sekel milli şuurunu meydana getiren ve tarihsel verilerle de desteklenen bu serüvene kısaca bir göz atalım.

\section{Krimhilda Savaşı ve Prens Çaba (Csaba)}

Avrupa Hunlarının büyük hakanı Attila'nın 453 yılındaki ani ölümü ardından Hun birliği büyük bir kaosa sürürüklenmiş, Türk veraset usulü gereğince varisleri arasında kıyasıya bir mücadeye yaşanmıştır. İşte bu mücadelelerden biri Sekel tarihi ve kültürü açısından oldukça önemli bir gelişmeye sahne olacaktır. Attila'nın Batı Roma İmparatoru III. Constantius'un kızı ve bir sonraki imparator III. Valentiniaus'un kız kardeşi olan Prenses Honoria (417-452) ile olan evliliği sonucu dünyaya geldiği söylenen oğulları Prens Aladár ve Prens Çaba (Csaba) kozlarını savaş meydanında paylaşmıştır. Simon Kézai kronikasında Attila'nın ölümünden sonra iki oğlu arasında Krimhilda Savaşı adı verilen kanlı bir mücadele yaşandığ 1 ve sonuçta Çaba'yı destekleyen sayıları 15.000 olan Hunlar mağlup edildiği belirtilmektedir. Çaba geriye kalan 3.000 Hun atlısı ile birlikte Yunanistan'a doğru çekilmiş, bu Hunlar Csigle denen yere yerleşerek Árpád (895-907) çağına kadar burada kalmışlardır. Kendilerini Prens Çaba'ya hasreden bu Hun bakiyesi, Macarlar Pannonia'yı fethettiği sirada tekrar gelerek onlara katıldılar ve Ruthenia'nın (Karpatlar) fethinde iştirak ettiler. ${ }^{29}$ Bugünkü Sekellerin ataları olduğu düşünülen bu Hun topluluğunun Macarlara katılımı XIII. yüzyıl başlarında Kral III. Belá'nın memuru olan ve asıl adı bilinmeyen Anonymus tarafından kaleme alınan Gesta Hungarorum adlı eserde aynen nakledilmektedir. Eserde Sekellerin Hun Kralı Attilla'nın halkı oldukları ve Macar Kralı Árpád'ın Pannonia'yı istilası sırasında ${ }^{30}$ onlara katılarak fetihlerde görev aldıkları söylenmektedir. ${ }^{31}$

Böylelikle Sekellerin milli tarihinde çok önemli bir simge olan Prens Çaba ve onun destansı mücadelesi aynı zamanda Macar tarihi içinde mühim bir motif olarak eski kroniklerde yerini almıştır. Sekellerin köklerini Büyük Hun Hakanı Attila'ya kadar götüren bu olaylar zinciri aslında Macarların 896 yllında Pannonia'ya gelerek “yurt tutuş" hadisesini gerçekleştiren Árpád için de önemli bir dayanak noktası oluşturmuştur. Árpád yurt tutuş hadisesi ardından kendisinin de Attila'nın soyundan geldiğini söyleyerek bu topraklarda hükümranlığını eski geleneklere bağlamış ve iktidarını sağlamlaştırmıştır. Zira Anonymus'un eserinde Árpád kendisi ve kendisinden sonra Macar tahtına oturacak olanların Attila'nın

\footnotetext{
${ }^{29}$ Kézai, age, s. 30-31.

${ }^{30}$ Anonymus Macar atlılarının Tuna'yı geçerek Pannonia'yı fethetmesini kroniğinde ayrıntılı olarak nakletmektedir. Anlatılana göre Macarlar Tuna'nın diğer kıyısına geçtiler. Tuna kıyısındaki Felhévizekig'de karargâh kurduklarında Pannonia arazisi boyunca yaşayan Romalılar bunu duyup, kaçarak canlarını kurtardılar. Ertesi gün Prens Árpád ve beraberindeki bütün Macar savaşçıları Kral Attila'nın şehrine girdiler. Onlar diğerleri dışında bütün kraliyet saraylarının ve vakıfların harap olduğunu gördüler ve muazzam taş binalara hayran kaldılar. Kral Attila'nın şehrini onun soyundan gelen Prens Árpád'ın savaşmadan almayı hak etmesi anlatılandan daha mutlu bir hadise idi. Macarlar Attila'nın sarayında her gün büyük bir sevinçle şölenler tertip ettiler, zithers ve borular eşliğinde ozanlar tüm şarkılarını onlara sundular. Prens Árpád yanındakilere büyük topraklar ve mülkler verdi ve bu olay duyulunca çok sayıda kişi onun yanına akın etti ve memnuniyetle ona katıldılar. Bkz. Anonymus, age, s. 24.

${ }^{31}$ Age, s. 26.
} 
soyundan geldiklerini belirtmektedir. ${ }^{32}$ Bu suretle Macar kralları ve Sekel halkı arasında bir bağl1l1k meydana gelmiş ve bu birliktelik savaş meydanlarında perçinlenmiştir.

Yukarıda değindiğimiz üzere Hun tarihsel mirası yurt tutuş ile birlikte yeni bir boyut kazanarak Macar ve Sekel halkları arasında bir kaynaşmaya neden olmuştur. Burada en önemli birleştirici unsur Attila ve Hunlarına duyulan derin saygı ve adanmışlık duygusunun iki toplum nazarında da milli bir şuura dönüşmüş olmasıdır. Şimdi bu şuurun ortaya çıkmasına katkı sağlayan destanlara bir göz atarak Sekel halkının mitolojik köklerine 1şık tutmaya çalışacağız.

\section{Milli Destanlara Göre Sekellerin Menşei}

Sekellerin bugün dahi muhafaza ettikleri destanlar kendi benliklerini hasrettikleri yegâne hazineleri durumundadır. Bugün maalesef ki azınlık durumunda yaşamını idame ettiren Sekel halkı, varoluş reçetesi olarak geçmişine ve özgün kültürüne sarılmıştır. Öncelikle ortak Hun miras $^{33}$ ve uzun y1llar birlikte yaşamaları sebebiyle Macar epik edebiyatının da etkisinde kalan Sekel toplumu, kendilerine has bir takım inanç ve adetlerini kısmen de olsa korumayı bilmiştir. Biz burada yukarıda dikkat çektiğimiz üzere Hun-Macar-Sekel tarihi ve kültürel birlikteliğinden bağımsız bir Sekel menşe fikri ortaya koymayacağız. Bu sebeple tarihi süreç içinde eski Türk mitolojisinden de esintilerin görüldüğü ve ortak mirasa işaret eden menşe hikâyelerini birlikte vermek uygun olacaktır.

\section{Alageyik Efsanesi (Csodaszarvas-monda)}

Macar ve Sekel uluslarının ortak atası olarak kabul edilen Avrupa Hunlarının en önemli

tarihi kaynağı Bizans tarihçisi Jordanes, onların menşeine dair bir takım efsanelere yer vermiştir. Anlatılana göre: Eski Hun avc1ları kendi adetlerine göre bir sürgün avı yapıyorlarmış. Avlana, avlana Maeotis bataklıklarının iç kısmına doğru gitmişler. Bu sırada nereden geldiğini bilmedikleri bir dişi geyik çıkmış karşılarına. Dişi geyik onlara bataklığa doğru yol göstermeye başlamış. Onlar da ellerinde olmadan dişi geyiğin peşinden gitmişler. Geyik bazen gidiyor, bazen de durarak onlara bakıyormuş. Avcılar geyiği ha vurduk, ha vuracağız derken iyice bataklığın içine girmişler. Az sonra bataklığın öbür kenarı görünmüş. Hâlbuki Hunlar bu bataklığı geçilmez bir okyanus kadar büyük görürlermiş. Bataklığın karşı yakasında ise İskitlerin memleketi varmış. Hun avcıları İskit memleketine ayak basar basmaz, geyik de birden bire kaybolmuş. Bu efsane, Hunların henüz Güney Rusya civarında oturdukları bir dönemin hatıralarını barındırmaktadır. Zira anlatılan bataklık Güney Rusya'dadır. Jordanes ayrıca Hunların İskitlerden nefret ettiklerini söylemektedir. Anlaşılan o ki bu efsane bir türeyiş efsanesinden çok İskit yurdunun Hunlar tarafından alınışını anlatan tarih olayıdır. Bahaeddin Ögel bu efsanedeki geyik ve bataklık motifinin Oğuz Kağan Destanı'ndaki kurt ve bataklık motifi ile alakalı olabileceği görüşündedir. ${ }^{34}$

Avrupa Hunlarının Güney Rusya'daki kalıntılarından olan Kutigur ve Utigurların menşe efsaneleri de aşağı yukarı Hunlarınki ile aynıdır. Efsanede yine dişi bir geyik bu kabilelerin avcılarını bir denize çekmiştir. Efsaneye göre: Vaktiyle Kimmer Kralının Kutigur ve Utigur adlı iki oğlu varmış. Günlerden bir gün, bu iki çocuk avlanmak için çıkarlar. Av için dolaşıp dururken dişi bir geyiğe rastlarlar ve iki kardeş geyiği hemen kovalamaya başlar. Geyik kaçar, çocuklar kovalar ve nihayet bir denizin kenarına gelirler. Çocuklar geyiği denizin kenarında sıkıştırıp vurmak isterler. Fakat geyik denize atlayıp yüzmeye başlar. Çocuklar da yüzerek

\footnotetext{
${ }^{32}$ Age, s. 10 .

${ }^{33}$ Sekel tarihi ve kültürü üzerinde derin izler bırakan Hun mirası hakkında bkz. Borbála Obrusánszky, "Székelyföld Hun Hagyatéka”, Mikes International, Volume XII., Issue 3., Lahey 2001, 96-106.

${ }^{34}$ Bahaeddin Ögel, Türk Mitolojisi, C. I, TTK Basımevi, Ankara 2010, s. 578-579.
} 
geyiğin peşinden giderler. Geyik önde, çocuklar arkada yüzerek karşı kıyıya geçerler. Çocuklar karaya ayak basar basmaz, geyik de birden bire gözden kaybolur. ${ }^{35}$

Hun efsanelerindeki bataklık burada deniz olmuştur. İlginçtir ki Moğol efsanelerinde de dişi geyik ve deniz geçme hadisesi aynen yer almaktadır. ${ }^{36}$ Geyik motifi içeren Macar menşe efsanelerinden biri ise şöyledir: Vakti zamanında bazı kimseler avlanmak için Maeotis bataklığına gitmişlerdi. Tıpkı bir çölü andıran bir bölgeye geldikleri zaman, karşılarına birden bire bir geyik çıktı. Avcılar hemen geyiğin peşine düştüler. Geyik kaçtı, avcılar kovaladı ve nihayet öyle bir yere geldiler ki geyik birden bire yok oldu. Avcılar hemen geyiği aramaya koyuldular ancak bulamadılar. Sanki Tanrı onu gökten çekmiş gibiydi. Avcılar geri dönmek istediklerinde bu defa yollarını kaybettiler. Bataklık ortasında mahsur kalan avcılar burada yaşamaya başladılar ve tam beş yıl bu bölgede kaldılar. Altıncı sene bataklığın ortasında kral Bela'nın eşlerine ve çocuklarına rastladılar. Nedense bu ailenin erkekleri tamamen ölmüş ve erkeksiz kalmışlardı. Avcılar kadınları ve çocukları alarak kendi bataklıklarına götürdüler. Bu aileler arasında Alan Prensi Dula'nın iki kızı da bulunuyordu. Hunor ve Magor adlı iki avcı bu prensesleri görünce onlarla evlendiler ve bu suretle de Macar milleti meydana geldi. ${ }^{37}$

\section{Tuğrul Kuşu (A Turul-monda)}

Macar menşe efsanelerinin bir diğer motifi de Macaristan Krallığı'nı tesis eden Árpád Hanedanı'nın türeyişini anlatan Tuğrul Efsanesi”dir. Bu efsanede hanedanın kurucusu olan Árpád'ın babası olan Almos'un (820-895) dünyaya geliş hadisesi anlatılmaktadır. Efsane şöyledir:

Macar Kralı Almos'un babası Ügyek kutsal kitaplarının yazıldı ̆̆ efsanevi hükümdar Magog'un (Me'cüc) soyundan geliyordu. Bu hükümdar, İskit ülkelerinde uzun zaman hakanlık yapmış ve soylu krallar arasında sayılmaya başlamıştı. DentüMogyerban adll bir yerde oturuyordu. Eunedubelianuslarm reisi olan bir kabile başkanının kızı ile evlenmişti. Bu kızın adı da, Emese idi. Kral Ügyek'in bu kızdan Almos adında bir oğlu oldu. Bu çocuğa Almos adının verilmesinin nedeni kutsal ve insanüstü bir doğumla dünyaya gelmiş olmasındandl. Almos'un annesi henüz daha ona hamile kalmadan rüyasında bir Tuğrul kuşu gördü. Tuğrul kadının etrafinda uçarak dolaşmış ve sonra da rahmine girmişti. Bir süre sonra da kadın gebe kaldığını anlamış, ayı ve günü dolduktan sonra da çocuğunu doğurmuştu. Fakat bu çocuğun doğumu sırasında da fevkalade olaylar meydana gelmişti. Kadının karnından seller boşalarak coşkun çağlayanlar halinde akmışt. Bunu duyanlar ise büyük ve muzaffer bir hanedanın doğduğunu müjdelediler. Gerçekten de çocuk büyüyüp hükümdar olunca, herkesin ümit ettiği gibi bir kral oldu.

Anynmos'a göre Árpád Hanedanı silsilesi Kral Nemrud, Hunor, Attila, Ügyek (Emese'nin eşi), Almos, Árpád şeklinde tecelli etmiştir. ${ }^{38}$

\section{Samanyolu Efsanesi (Hadak Útja)}

Sekellerin menşe efsaneleri yukarıda anlatılan Hun ve Macar geleneğinden bağımsız değildir. Ancak bir Sekel'i bir Macar'dan ayıran yegâne husus Prens Çaba'ya atfedilen büyük

\footnotetext{
${ }^{35}$ Age, s. 579.

${ }^{36}$ Geyik ve deniz figürü içeren Moğol türeyiş efsanesi hakkında bkz. Moğolların Gizli Tarihi, Çev. Ahmet Temir, TTK Basımevi, Ankara 2010, s. 3.

37 Ögel, age, s. 581.

${ }^{38}$ Anonymus, age, s. 5.
} 
değerden ileri gelmektedir ${ }^{39}$. Prens Çaba Sekel milli kültüründe bir ata olmaktan öte adeta bir aziz olarak tasavvur edilmiş ve hatırası gönüllerde yer etmiştir. Sekeller arasında Hadak Útja olarak bilinen efsaneye göre Sekel halkı varlığını tehdit edici bir tehlike ile karşılaştığı vakit Saman Yolu galaksisi içendeki yıldızlarda bulunan Prens Çaba ve ordusu gökyüzünden inerek onları bu beladan kurtaracaktır. ${ }^{40} \mathrm{Bu}$ inanç en zor zamanlarda Sekel toplumunu bir arada tutan ve geleceğe umutla bakmalarını sağlayan itici bir güç olmuştur.

Prens Çaba'nın Sekeller arasındaki hatırası o derece kuvvetlidir ki Sekel milli marşında bile kendisine yer bulmuştur:

\section{Sekel Milli Marşı}

\section{Macarca}

Ki tudja merre, merre visz a végzet Göröngyös úton, sötét éjjelen. Segitsd még egyszer gyözelemre néped, Csaba királyfi csillagösvényen.

Maroknyi székely porlik, mint a szikla Népek harcának zajló tengeren.

Fejünk az ár ezerszer elboritja, Ne hagyd elveszni Erdélyt, Istenünk!

\section{Türkçe}

Kim bilebilirdi ki kader tutup bizi buraya getireceğini, Gecenin karanllk bir yolunda! Milletine zafer için yardım et, Prens Çaba yıldız yolunda.

Yurdumuz Szekely dağlar gibi yıkıldı Milletlerin savaşının firtınasında. Başımız her zaman diktir, Erdel topraklarını korumamıza yardım et ey tanrı!
History Studies

Bununla birlikte Macar milli şairi Arany János Prens Çaba'nın destansı mücadelesini ölümsüzleştiren bir üçlemeye imza atmış ve gelecek kuşaklara miras bırakmıştır. ${ }^{41}$

\section{Sekel Yazısı Neyi İfade Ediyor?}

Sekellerin tarihçiler ve filologlar tarafindan ilgi çekmesinin en önemli nedeni kendilerine has bir yazı tarzına sahip olmalarıdır. Zira bu topluluğun kullandığ 1 yazı başta Macarlar olmak üzere hiçbir Avrupa milletinin yazı karakterine benzememektedir. Türk yazısının bir versiyonu olan Sekel yazısının Macarlar arasında "rovasiras" (oyma yazısı) olarak adlandırıldığı ve MS 1000 yıllarında iktidarda olan I. Istvan'ın ülke çapında eski inanışlar ve eski yazıyı yasaklaması üzerine Sekellerin bu yazıyı atalardan kalma kutsal yazı olarak kabul ederek başta kiliseler olmak üzere muhtelif yerlerin zor görünen gizli yerlerine yazdıkları sanılmaktadır. Kullandıkları bu yazı sistemi aynı zamanda Sekelleri kaybolmaktan kurtaran bir zırh vazifesi görmüştür. ${ }^{42}$

Sekellerin kullandığı yazı XIII. yüzyıldan itibaren çeşitli kaynaklarda geçmektedir. Tarihinden emin olduğumuz en eski kalıntı XV. yüzyıla aittir. Fakat tarihi tespit edilememiş daha eski buluntular da mevcuttur. ${ }^{43}$ Sekellerin uzun süre Macarlar arasında kalmaları ve dillerinin Macarca olması Sekel yazısı ve alfabesinin sonraki dönemlerde Macarlar tarafından sahiplenilmesine sebebiyet vermiştir. Ancak tarihte "Macar Yazısı" olarak adlandırılan bu

\footnotetext{
39 Prens Çaba Efsanesi'nin Macar ve Sekel milli kültüründeki hususiyeti için bkz. Gábor Solti, "Piliscsaba Legendája" Magyar Irodalmi Hirlevél 64. Megjelenése, 2012, s. 5-6.

${ }^{40}$ Sebestyén Gyula, A Magyar Honfoglalas Mondai, Budapest 1904, s. 544; S. Kardoss Lajos, A Szekely Nemzet Tortenete es Alkotmanya, Budapest 1927, s. 7.

${ }^{41}$ Çaba Üçlemesi için bkz. Arany János Összes Költeményel, C. I-II, Szepirodalmi Könvykiadao, Budapest 1978.

42 İsmail Doğan, Atilla 'nın Torunları Sekeller, Yeni Avrasya Yayınları, Ankara 2004, s. 19.

${ }^{43}$ Vasary, agm, s. 55.
} 
yazıyı ilk kullananların Sekeller olduğu çok açık bir şekilde ortadadır. Macar topraklarında bu yazı ile yazılmış tek bir eser dahi bulunamamıştır. ${ }^{44}$ Sekel oyma yazısının Macarlardan bağımsız olarak geliştiği tarihi kayıtlarca da sabittir.

Simon Kézai'nin kroniklerinde Sekellerin Macar yazısına hiç benzemeyen bu yazı tarzını Ulahlardan aldıkları kaydedilmiştir. Bu bilgi tarihi ve filolojik gerçeklerle bağdaşmamakla birlikte burada dikkat edilmesi gereken nokta Sekellerin kendilerine has bir yazı kullanıyor olmalarıdır. ${ }^{45} 1488$ senesinde Thuroczi, Sekellerin İskit yazısını unutmayıp kâğıt ve mürekkep yardımı ile değil değneklerle boyamak suretiyle çentik tarzında yazdıklarını belirtmektedir. ${ }^{46}$ Ulah Mikloş, eserinde Sekellerin Macarlardan farklı olarak duygu ve düşüncelerini kendilerine has yazı stilleriyle dile getirdiklerini belirtmiştir. ${ }^{47} 1559$ tarihinde Macar dilinde umumi bir tarih kitabı kaleme alan ve aslen bir Sekel olan Benczedi Szekely Istvan'a göre Sekellerin kullandıkları bu yazı onlara Hunlardan intikal etmiştir. ${ }^{48}$ Antal ise Sekellerin Macarlarla aynı dili konuşmalarına rağmen yazılarının onlardan farklı olduğuna dikkat çekmektedir. ${ }^{49} 1655$ yılında Komaromi Csipkes György Latince kaleme aldığı eserinde Sekel yazısının doğu kökenli olduğunu ve hiçbir Avrupa yazı karakteriyle uyuşmadığını söylemiştir. ${ }^{50}$

Sonuç itibariyle Latin ve Yunan harfleriyle benzerlik göstermeyen, Avrupa dillerinin aksine sağdan sola doğru ilerleyen Sekel oyma yazısının, Türk runik yazısının değişik bir varyantı olduğu gerçeği ilim adamları tarafından kati surette kabul görmüştür. $\mathrm{Bu}$ yazı numunelerin kayıtlı bulunduğu Sekel Yazıtları sayesinde atalarından kalma bir geleneği devam ettiren Sekeller, etnik yönden oldukça karışık bir bölgede milli benliklerini muhafaza etmeyi bilmişler, dolayısıyla da Türk tarih yazıcılığına katkıda bulunmuşlardır. Onlardan kalma yazıtlar arasında Szekelyderzs, Csikszent-Mihaly, İstanbul ve Bögöz yazıtları ile XV. yüzyıldan kalan ve tahta bir çubuk üzerinden Marsigli adında bir İtalyan kontu tarafından kopya edilen kayıt önemli bir yer tutmaktadır.

\section{Sonuc}

Sekeller bulundukları coğrafya ve inançları gereği Avrupa medeniyetinin bir parçası olmaları yanında etnik ve kültürel açıdan farklılık arz etmektedirler. Etnik kökenleri hakkında birbirinden oldukça farklı iddiaların gündeme gelmesi onların eşsiz ve kendine has kültürlerinden ileri gelmektedir. Sonradan dâhil oldukları bir coğrafyada Greko-Romen ve Germanik kültürlerle temas halinde olan, Slavyen toplulukların yanı başında bulunan ve Türkî unsurların kültürel izlerini bünyesinde barındıran bu toplumun etnik kökeni hakkında

\footnotetext{
${ }^{44}$ H. Namık Orkun, Eski Türk Yazıtları, TDK Yayınları, Ankara 1994, s. 659-660. Bugün de Sekel oyma yazısının ekseriyetle Transilvanya ve çevresinde göze çarpması ve Macarların yoğunlukta olduğu bölgelerde Sekel yazısına rastlanmıyor olması Orkun'un bu yazının Sekellere has bir yazı olduğu konusundaki görüşünü destekeler niteliktedir.

${ }^{45}$ Orkun, age, s. 660.

${ }^{46}$ Age, s. 660.

${ }^{47}$ Mikloş'un ifadesine göre Sekeller iç düşüncelerinin ve her günkü arzularının ifadesini kâğıt ve mürekkep veya diğer dillerin harflerini kullanmakla değil tahta çubuklarla bazı işaretler çentmekle aralarında bir mana ifade ederler ve böyle çentik değnekleri dostlarına haber veya mektup makamında kullanırlar. Bkz. Age, s. 661 .

${ }^{48}$ Istvan eserinde "Şimdi dâhi diğer Macarlardan kanunları ve yazıları ile ayrılırlar ki Hun tarzındaki Sekel harfleri bugün dahi kullanılmaktadır" demektedir. Bkz. Age, s. 661.

49 "Sekeller dillerine nazaran da Macarlarla her yönden birleşmezler. Eskiler gibi konuşurlar. Harf gibi bazı işaretleri dört köşeli tahta bastonlarla çenterler ve satır tıpk Yahudiler, Misırlılar ve Türkler gibi sağdan sola doğru gider. Böyle asgari iki satır yanına bazı noktalar koymak suretiyle de işaretlerin adedine nazaran pek çok mana ifade etmektedirler. Yerliler arasında hunların da bu yazı işaretlerini kullandıklarına dair rivayetler bulunmaktadir.” Bkz. Age, s. 662.

${ }^{50}$ György eserinde;"Bunlarda Erdel'de bugün dahi belirli bir yerli yazı tarzl vardır ki bu, eski cetlerinden, İskitlerden birçok asırlardan beri haleflerine kalmış bulunuyor ve Avrupa'ya doğudan getirilen bu yazı tarzı bugün dahi kullaniliyor." demektedir. Bkz. Age, s. 662.
} 
böylesine farklı iddiaların ortaya atılmış olması şaşırtıcı olmasa gerektir. XII. asır ile birlikte Macarlara katılan Sekellerin eski Macar kroniklerinde Attilla'nın oğlu Çaba'nın neslinden geldiğine dair bilgiler büyük oranda Sekel toplumu içinde benimsenmiş ve kendilerini aynı geleneğe hasreden Árpád hanedanı ile işbirliğine gitmelerini kolaylaştırmıştır. XIX. asır ile birlikte doruğa ulaşan Türkoloji çalışmaları Sekel etnisitesini de tasnif dışı bırakmayarak onların en eski tarihleri hakkında bir takım fikirlerin oluşmasına vesile olmuştur. Tarihi ve filolojik veriler Türklerle olan yakın akrabalığı işaret etmekte ancak Hun, Avar, Hazar ve Bulgar kabilelerinin birbirine karıştığı bu coğrafyada kesin bir menşe fikri ortaya konulamamaktadır. Bununla birlikte bu topraklarda hayat bulan Attila ve Hunları Sekel, Macar ve Türk etnisitesini birleştiren ortak bir miras olarak karşımızda durmaktadır. Kısacası Sekellerin Macarlığı, Macarların Hunlarla olan tarihsel bağları ile alakalıdır ve bu iki toplumunda genlerinde Orta Asya Türk kültürünün esintileri açıç̧a hissedilmektedir. Bu nedenle türeyiş efsaneleri de benzerlik göstermektedir. Burada Sekeller arasında Prens Çaba'ya biçilen değer bir ayrışmaya sebep olsa da yine baskın olan Hunların tarihsel mirasıdır. Sekelleri Macarlardan ayıran bir diğer nokta da Sekel oyma yazısıdır ki bunun da Türk runik yazı geleneği ile olan bağlantısı konunun uzmanları tarafindan ortaya konulmaktadır.

\section{KAYNAKÇA}

Anonymus, Gesta Hungarorum, Fordította: Pais Dezső, Magyar Helikon 1977.

BALÁZS János, Levédia, Nyék... és a Székelyek Eredete, Magyar Deákság, Anyanyelvünk és az Európai Nyelvi Modell, Budapest 1980.

BÁLİNT Hóman, A Székelyek Eredete, A Magyar Nyelvtudományi Társaság Kiadványai 17, Budapest.1921. ,"Szekelyliler", Çev. Hamit Z. Koşay, Belleten, C. V, S. 20, TTK Basımevi, Ankara 1941, s. 591-606.

BENKŐ Loránd, "Nyelvész Szemmel a Székelyekről”, Beszélgetés Benkő Loránd Akadémikussal, Új Tükör, C. 7, Szeged 1980.

BENKÖ József, Transsilvania Specialis Erdély Földje és Népe, C. I., Fordította: Szabó György, Kriterion Könyvkiadó, Bukarest-Koloszvar 1999.

BONFINI Antonio, A Magyar Történelem Tizedei, Fordította: Péter Kulcsár, Balassi Kiadó, Budapest 1995.

BOROVSZKY Samu, “Hun-Magyar Rokonságról”, Ethnographia, 1894.

DOĞAN İsmail, Atilla'nın Torunları Sekeller, Yeni Avrasya Yayınları, Ankara 2004.

ECKHART F., Macaristan Tarihi, Çev. İbrahim Kafesoğlu, TTK Basımevi, Ankara 2010.

ERDÉLYİ László, A Székelyek Eredete, Szent Bonaventura Könyvnyomda, Kolozsvár 1918.

GÖMEÇ Saadettin, “Türk Tarihinde Sek El-Çik-Çigil Meselesi”, Ankara Üniversitesi Dil ve Tarih-Coğrafya Fakültesi Türkoloji Dergisi, C. 18, S. 2 (2011), s. 49-60.

GYÖRFFY György, A Székelyek Eredete és Településük Története, in Erdély és népei, szerk. Mályusz Elemér, Budapest 1941.

GYULA Sebestyén, A Magyar Honfoglalas Mondai, Budapest 1904. 
JÁNOS Arany, Összes Költeményeı, C. I-II, Szepirodalmi Könvykiadao, Budapest 1978.

Képes Krónika, Fordította: Geréb László, Magyar Hírlap és Maecenas Kıadó, Budapest 1993.

KARÁCSONYİ János, A Székelyek Eredete És Erdélybe Való Települése, Budapest 1905. , A Székelyek Ösei és a Székely Magyarok, Cluj-Kolozsvár 1924.

KÉZAI Simon, Magyar Krónıkája, Szerkeszti: Radó Antal, Budapest 1901.

KORDÉ Zoltán, Székelykérdés Története, Székelyudvarhely 1991.

KRISTÓ Gyula, Levedi Törzsszövetségétöl Szent István Államáig, Budapest 1980.

LAJOS S. Kardoss, A Szekely Nemzet Tortenete es Alkotmanya, Budapest 1927.

Moğolların Gizli Tarihi, Çev. Ahmet Temir, TTK Basımevi, Ankara 2010.

LÁSZLÓ Gyula, Árpád Népe, Monográfia, Magyar Helikon, Budapest 1988.

MÁLYUSZ Elemér, A Székelység Eredetéröl, Emlékkönyv Melich János Hetvenedik Születésnapjára, Budapest 1942.

MESTERHÁZY Károly, Nemzetségi Szervezet és az Osztályviszonyok Kialakulása a Honfoglaló Magyarságnál,Budapest 1980.

MíKLÓS Asztalos, A székelyek östörténete letelepedésükig, Cluj-Kolozsvár 1932.

MOÓR Elemér, A Honfoglaló Magyarság Megtelepülése és a Székelyek Eredete, Szeged 1944.

NAGY Géza, Az Eszegel Bolgárok Neve, Századok 1914.

NÉMETH Gyula, A Székelyek Eredetének Kérdése, Szeged 1935.

OBRUSÁNSZKY Borbála, "Székelyföld Hun Hagyatéka”, Mikes International, Volume XII., Issue 3., Lahey 2001, 96-106.

ORKUN H. Namık, Eski Türk Yazıtları, TDK Yayınları, Ankara 1994.

ÖGEL Bahaeddin,"Sekellerin Ataları Hakkında (Sikil, Esgil Boyları)”, Belleten, C. IX, S. 36, TTK Basımevi, Ankara 1945, s. 469-484.

, Türk Mitolojisi, C. I, TTK Basımevi, Ankara 2010.

PAİS Dezső, A magyarsággal Kapcsolatos IX-X. Századi Népelemek és Népmozgalmak. A Székelyek Eredetéhez és a Székelység Kialakulásához, Magyar Nyelv, 1967.

PÁL Hunfalvy, Magyarország Ethnographiája, A Magyar Tudományos Akadémia Könyvkiadó-Vállalata, Budapest 1876.

PAULER Gyula, A Vezerek Kora István Kırályıg, Magyar İskutatis Kiadása, Buenos Aires 1974.

RASONYİ László, “Ortaçağ’da, Erdel'de Türklügün İzleri”, Belleten, C. II, S. 5/6, TTK Basımevi, Ankara 1938, s. 107-122.

, Doğu Avrupa'da Türklük, Selenge Yayınları, İstanbul 2006.

RÉTHY László, “A székelyek es a Magyar Honfoglalás”, ”, Ethnographia, 1890. 
SOLTİ Gábor, "Piliscsaba Legendája” Magyar Irodalmi Hírlevél 64. Megjelenése, 2012, s. 5-6.

SEBESTYÉN Gyula, “Az Avar-Székely Kapcsolat Emlékei” Ethnographia, 1899.

, Az Avar-Székely Kapcsolat Pere, Válasz Thúry Józsefnek, Erdélyi Múzeum 1899.

SZÜCS Jenő, “A Középkori Magyarország Népei”, I. História, 1982.

TAGÁNYİ Károly, “A Honfoglalás és Erdély”, Ethnographia, 1890.

TİMON Sámuel, Epitome Chronologica Rerum Hungaricarum, Cassovia 1734.

THURÓCZİ János, A Magyarok Krónikája, Helikon Kiadó, Budapest 1986.

THÚRY József, A Székelyek Eredete, Erdélyi Múzeum, 1898.

VÁSÁRY István, “Doğu Avrupa'nın Runik Yazı Sistemleri Üzerine”, TDAY-B, Ankara 1993, s. 51-59. 